\title{
GENERATIVE LEARNING MODEL IN MATHEMATICS: A SOLUTION TO IMPROVE PROBLEM SOLVING AND CREATIVE THINKING SKILL
}

\author{
Kusairi $^{*}$, Syaiful ${ }^{2}$, Haryanto ${ }^{3}$ \\ ${ }^{1,2,3}$ Department of Mathematics Education, Postgraduate Program, Universitas Jambi, Indonesia \\ *Corresponding author: kusairi.samsungj3@gmail.com
}

\begin{tabular}{|c|c|}
\hline Article Info & ABSTRACT \\
\hline Article history: & The purpose of this study is to determine the effect of Generative \\
\hline Received: May 10, 2020 & creative thinking skills. The method used in this \\
\hline Acc & periment method with post-test only design. The sample in this \\
\hline $\begin{array}{l}\text { Published: November } 30 \text {, } \\
2020\end{array}$ & $\begin{array}{l}\text { study was } 75 \text { fifth grade students at SDIT Al-Azhar Jambi taken by } \\
\text { random sampling technique. Data collection techniques using essay } \\
\text { tests of mathematical problem-solving and mathematical creative }\end{array}$ \\
\hline & $\begin{array}{l}\text { thinking skills. Data analysis was done by normality test, } \\
\text { homogeneity and hypothesis testing using one-way ANOVA by }\end{array}$ \\
\hline $\begin{array}{l}\text { Creative thinking } \\
\text { Cube and block material } \\
\text { Generative Learning Model } \\
\text { Problem solving skills } \\
\text { Student worksheet }\end{array}$ & $\begin{array}{l}\text { SPSS software 25.0. The results of data analysis show that there is } \\
\text { an effect of Generative learning model on mathematical problem } \\
\text { solving and mathematical creative thinking skills, and the } \\
\text { application of Generative learning model with student worksheet } \\
\text { are better than just Generative learning model or conventional } \\
\text { learning model. }\end{array}$ \\
\hline
\end{tabular}

PEMBELAJARAN GENERATIF PADA MATEMATIKA: SOLUSI UNTUK MENINGKATKAN KEMAMPUAN PEMECAHAN MASALAH DAN KEMAMPUAN BERPIKIR KREATIF

Kata Kunci:
Kemampuan berpikir kreatif
Materi kubus dan balok
Model pembelajaran
generatif
Kemampuan pemecahan
masalah
Lembar kerja peserta didik

\begin{abstract}
ABSTRAK
Tujuan dari penelitian ini yaitu untuk mengetahui pengaruh model pembelajaran Generatif terhadap kemampuan pemecahan masalah matematika dan berpikir kreatif matematis. Metode yang digunakan dalam penelitian ini yaitu metode penelitian Quasi Eksprimen Reseach dengan desain post-test only. Sampel dalam penelitian ini adalah 75 orang siswa kelas V di SDIT Al-Azhar Jambi yang diambil dengan teknik random sampling. Teknik pengumpulan data menggunakan tes essay kemampuan pemecahan masalah matematika dan berpikir kreatif matematis. Analisis data dengan uji normalitas, homogenitas dan uji hipotesis menggunakan ANOVA satu jalur dengan SPSS software 25.0. Hasil analisis data menunjukkan bahwa terdapat pengaruh model pembelajaran Generatif terhadap kemampuan pemecahan masalah matematika dan berpikir kreatif matematis dan model pembelajaran Generatif di tambah LKPD lebih baik dari model pembelajaran Generatif saja dan model pembelajaran konvensional.
\end{abstract}




\section{INTRODUCTION}

Students' thinking ability can be trained through independent habits in solving problems, so students are able to improve various competencies that exist in themselves [1]-[3]. The ability to solve problems is basically the main goal in learning [4], [5]. Mathematical thinking ability in a higher level is mathematical critical thinking skills and mathematical creative thinking skills [6]-[8]. Previously, many studies have revealed that the way students solve problems is a result of students' knowledge and experience, therefore teachers must be able to help students provide meaningful mathematics learning experiences and build students' mathematical problem solving abilities to deepen students' understanding in mathematics [9], [10].

Creative thinking is defined as a combination of logical thinking and divergent thinking based on intuition but still in consciousness [11]-[14]. When someone applies creative thinking in problem solving, divergent thinking will provide many ideas, this is useful in finding a solution. The steps of creative thinking include preparation, incubation, illumination and verification [15]-[17]. In the preparation stage, students must try to gather various information that is relevant to the problem. In the incubation stage, students must take a short break by not thinking about the problem. In the illumination stage, students have found idea or plan, but the idea is still in the form of an idea framework. The last stage is verification, at this stage students evaluate or re-confirm their answers to the problem, then implement the idea, if the solution works then the creative thinking process is complete.

One learning model that is believed to be able to improve students' mathematical creative thinking and problem solving skills is Generative Learning model [18], [19]. Generative learning is based on constructivism, with the basic assumption that knowledge is constructed in students' minds [20]. Generative learning uses the theory of constructivism which holds that students are not passive recipients of information, but students should actively participate in the learning process and in constructing the meaning of the information they receive. This means that knowledge is built in the student's mind and cannot be transferred from the teacher's mind to the student's mind [21], [22]. In this study, the Generative learning model is collaborated with student worksheets that contain cube and block material, as well as assignments and questions to measure students' mathematical problem solving and mathematical creative thinking skills.

Mathematical problem-solving and mathematical creative thinking skills are very important for students, these abilities will make students accustomed to thinking independently. Therefore, we try to examine the results of applying Generative learning models in the learning process. This research will provide information about the effect of Generative learning on mathematical problem-solving and mathematical creative thinking skills.

\section{METHOD}

This research is a quasi-experiment with post test-only design [23] the design of this research is presented in table 1 below.

Tabel 1. Post-test-only Design

\begin{tabular}{ccc}
\hline Experimental Class & Experimental Treatment & Post-test \\
\hline Control class & Conventional Learning & Post-test \\
\hline
\end{tabular}


The population in this study were all fifth-grade students at SDIT Al-Azhar Jambi, with 75 of students selected as samples with random sampling technique. This research lasted for one month with 8 meetings in the learning process and 1 meeting for the final learning test. The stage of the research procedure can be seen in Figure 1 below.

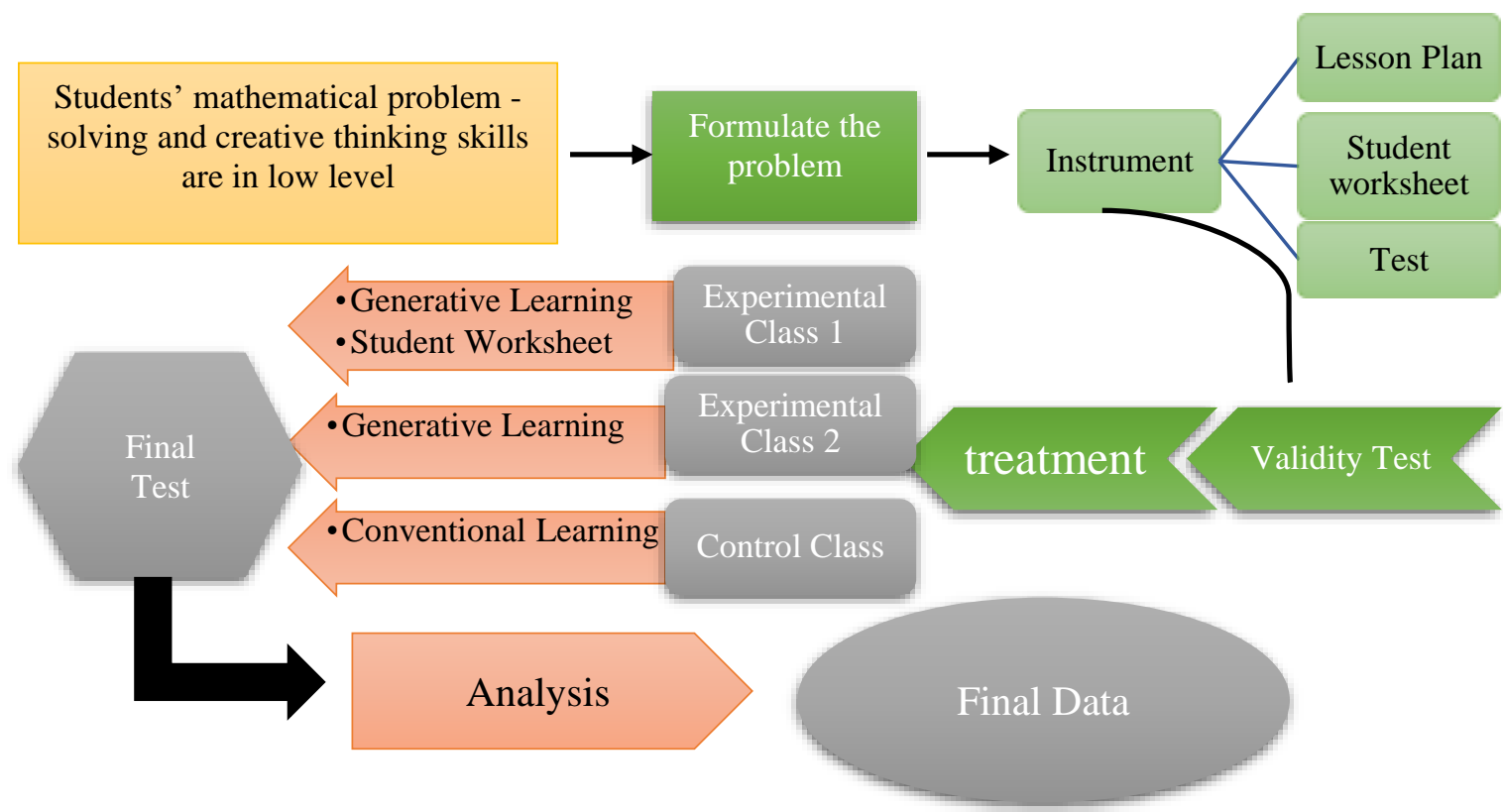

Figure 1. Research Procedure

In this study there are three types of variables, those are independent variable, dependent variable, and moderate variable. The independent variable in this study is the Generative Learning model, the dependet variable is mathematical problem-solving skills, and the moderate variable is mathematical creative thinking skills. Furthermore, to determine the effect of the generative learning model on students' mathematical problemsolving and mathematical creative thinking skills, we use the research design shown in Table 2 below.

Table 2. Research Design Framework

\begin{tabular}{lccc}
\hline \multicolumn{1}{c}{ Class } & Treatment & $\begin{array}{c}\text { Post-test (Problem } \\
\text { solving) }\end{array}$ & $\begin{array}{c}\text { Post-test (Creative } \\
\text { Thinking) }\end{array}$ \\
\hline $\begin{array}{l}\text { Experimental 1 (Generative } \\
\text { Learning + Student Worksheet) }\end{array}$ & $\mathrm{X}_{1}$ & $\mathrm{O}_{1}$ & $\mathrm{O}_{2}$ \\
$\begin{array}{l}\text { Experimental 2 (Generative } \\
\text { Learning) }\end{array}$ & $\mathrm{X}_{2}$ & $\mathrm{O}_{1}$ & $\mathrm{O}_{2}$ \\
Control (Conventional Learning) & $\mathrm{X}_{3}$ & $\mathrm{O}_{1}$ & $\mathrm{O}_{2}$ \\
\hline
\end{tabular}

Research data were collected through essay test. Next, we tested the data with a homogeneity test and a normality test as a prerequisite test. Hypothesis testing using oneway ANOVA with the help of SPSS Software 25.0.

\section{RESULTS AND DISCUSSION}

This research will reveal the effect of Generative learning model on mathematical problem-solving skills and mathematical creative thinking skills. Table $3 \& 4$ show the results of the statistical normality test with the Kolmogorov-Smirnov test at a significant level of 0,05 . 
Table 3. Normality Test Result for Mathematical Problem-Solving Test

\begin{tabular}{llccc}
\hline \multirow{2}{*}{ Class } & \multicolumn{3}{c}{ Kolmogorov-Smirnov(a) } \\
\cline { 3 - 5 } & & Statistic & df & Sig. \\
\hline Score & Experimental Class 1 & 0.165 & 24 & 0.089 \\
Score & Experimental Class 2 & 0.148 & 26 & 0.147 \\
Score & Control Class & 0.144 & 25 & 0.193 \\
\hline
\end{tabular}

Table 4. Normality Test Result for Creative Thinking Test

\begin{tabular}{llccc}
\hline \multirow{2}{*}{ kelas } & \multicolumn{3}{c}{ Kolmogorov-Smirnov(a) } \\
\cline { 3 - 5 } & & Statistic & df & Sig. \\
\hline Score & Experimental Class 1 & 0.155 & 24 & 0.141 \\
Score & Experimental Class 2 & 0.150 & 26 & 0.140 \\
Score & Control Class & 0.119 & 25 & 0.200 \\
\hline
\end{tabular}

Based on Tables 3 and 4 it can be seen that the significance value in the normality test is more than 0,05 . This shows that the sample groups came from populations that are normally distributed.

Homogeneity test was performed on the score data of students' mathematical problem solving skills [24], [3]. The test used is a barlett test with a significance level of 0,05 .

Table 5. Homogeneity Test Result

\begin{tabular}{cccc}
\hline Levene Statistic & df1 & df2 & Sig. \\
\hline 3.021 & 2 & 72 & 0.055 \\
\hline
\end{tabular}

Based on Table 5 above, it can be seen that the significance value is $0,055>0,05$. This shows that the sample comes from populations that have the same variance.

Hypothesis testing uses one-way analysis of variance with unequal cells. This data is shown in Table 6.

Table 6. Data Analysis Test Results using One-way Anova

\begin{tabular}{llccccc}
\hline & & $\begin{array}{c}\text { Sum of } \\
\text { Squares }\end{array}$ & df & $\begin{array}{c}\text { Mean } \\
\text { Square }\end{array}$ & F & Sig. \\
\hline Problem & Between Groups & 984.677 & 2 & 492.339 & 14.893 & 0.000 \\
Solving Skill & Within Groups & 2380.203 & 72 & 33.058 & & \\
& Total & 3364.880 & 74 & & & \\
\hline Creative & Between Groups & 372.798 & 2 & 186.399 & 4.552 & 0.014 \\
Thinking Skill & Within Groups & 2948.322 & 72 & 40.949 & & \\
& Total & 3321.120 & 74 & & & \\
\hline
\end{tabular}

Based on Table 6 , the data shows the significance value obtained is 0,000 , which means $0,000<0,05$ so $\mathrm{H}_{0}$ is rejected and $\mathrm{H}_{1}$ is accepted. So it can be concluded that there is an influence of the Generative learning model on problem solving skills.

Based on the One-way Anova test results with SPSS software, the significance value obtained is 0,014 , which means $0,014<0,05$, so $\mathrm{H}_{0}$ is rejected and $\mathrm{H}_{1}$ is accepted. So it can be concluded that there is an influence of Generative learning models on students' mathematical creative thinking skills.

The sample questions given to students are attached to Table 7. 
Table 7. Test Instrument

\begin{tabular}{cll}
\hline No & \multicolumn{1}{c}{ Question } & \multicolumn{1}{c}{ Analysis } \\
\hline 1 & $\begin{array}{l}\text { Gito's book is twice as many as Budi's. Hari's book is six } \\
\text { more than Budi's. If Budi has X books, how many books do } \\
\text { the three of them have? }\end{array}$ & $\begin{array}{l}\text { The test results showed that only } \\
20 \% \text { of students answered } \\
\text { correctly, while } 80 \% \text { of students } \\
\text { answered incorrectly. }\end{array}$ \\
2 A large cube is cut into three parts from \\
$\begin{array}{l}\text { different angles and produces many small } \\
\text { cubes like this picture. How many small } \\
\text { cubes might be produced? }\end{array}$
\end{tabular}

This research was conducted to determine the effect of Generative learning model on mathematical problem-solving and mathematical creative thinking skills. The learning process is carried out by applying the Generative learning model assisted by the use of student worksheets in the experimental class 1, applying the Generative learning model in the experimental class 2, and applying the conventional learning model in the control class. As the result, the experimental class showed higher scores (in both, problem-solving and creative thinking scores) compared to the control class scores. The average score for the mathematical problem solving in cube and beam topic in the experimental class 1 was 81.71, the experimental class 2 received an average score of 81.35, and the control class received the lowest average score: 73.84 . While the average score for creative thinking skills in the experimental class 1 was 80.25, the experimental class 2 got an average of 79.46 , and in the control class got an average of 75.16.

In learning using the Generative learning model there are 4 steps: (1) Introduction or exploration, (2) Focusing, (3) Challenges or stage of concept recognition, and (4) application of concepts or application stage [25]. In Generative learning, the application phase really helps the learning process, where at this stage we invite students to directly apply what they have learned so that students can learn by actively moving and doing. Implementation stage, at this stage students present the results of the discussion and other students respond to the results of the presentation of their friends, at this stage students can learn by speaking and listening. Furthermore, students are required to conduct discussions and work on the assignments in the student worksheet in groups. In the experimental class 1 , the presentation of the results of the discussion was done by asking students to do the work on the board, at this stage, teacher selected students who must solve the problem, so it is expected that all students in the group understand exactly what the group is discussing and doing. In the experimental class 2 , the presentation of the results of the discussion was done by inviting students to work on the assignments the teacher had given on the board, in this case, the one who chose the students who had to solve the problems was the teacher, so, it was hoped that all students in the group understood exactly what was discussed and done in their group. In the control class, students did not make presentations, they only worked on the questions given by the teacher, then the teacher checked their answers. This finding is supported by the results of previous studies conducted by Arif Rahman Hakim who stated that the application of generative learning model significantly affected the improvement of problem solving abilities[26], [27].

Another basic principle that is also applied in this research is that the learning process does not mean consuming (in this case means students only receive knowledge), so in the application of generative learning model, we make sure that students are required to be active in creative thinking (student centered). So, it is not surprising if we found that generative learning model made a major influence on students' mathematical creative

258 Indonesian Journal of Science and Mathematics Education ( I J S M E ) 
thinking skills. This finding is also supported by previous research conducted by Dewi Supriyanti which stated that the application of Generative learning can improve mathematical creative thinking skills better than discovery learning [21]. Other research result also show that students' mathematical creative thinking skills who learn with Generative learning is better than students who learn with discovery learning [28]. Thus, Generative learning can be a solution to improve mathematical creative thinking skills [29], [30].

\section{CONCLUSION}

Based on the results of the study, it can be concluded that: (1) there is an effect of the application of Generative learning model and the use of student woksheets on mathematical problem solving skills of fifth grade students at SDIT Al-Azhar Jambi, (2) There is an effect of Generative learning model on mathematical creative thinking skills of grade fifth students of SDIT Al-Azhar Jambi. Not all learning models are suitable to be applied in mathematics learning, therefore, there is a need to choose an appropriate learning model according to the topic. However, Generative learning models can be a good alternative in the learning process to improve students' mathematical cproblem solvingand creative thinking skills.

\section{REFERENCES}

[1] T. S. Sumartini And K. P. Matematis, "Peningkatan Kemampuan Pemecahan Masalah Matematis Siswa Melalui Pembelajaran Berbasis Masalah,” J. Pendidik. Mat. Stkip Garut Jurnalmtk.Stkip-Garut.Ac.Id, Vol. 5, 2016.

[2] D. Hamdani, K. Eva, And S. Indra, "Pengaruh Model Pembelajaran Generatif dengan Menggunakan Alat Peraga Terhadap Pemahaman Konsep Cahaya Kelas VIII di SMP Negeri 7 Kota Bengkulu," Exacta, 2012.

[3] R. S. Sinaga, "Pengaruh Model Pembelajaran Generatif Terhadap Pemecahan Masalah Matematika pada Materi Persamaan Linier Dua Variabel Kelas X SMK Swasta," Vol. 12, No. 1, Pp. 26-31, 2020.

[4] R. . Dahar, Teori-Teori Belajar dan Pembelajaran. 2011.

[5] D. D. Samo, "Kreativitas Siswa dalam Memecahkan Masalah Matematika Ditinjau dari Kemampuan Matematika Siswa," Admathedu J. Ilm. Pendidik. Mat. Ilmu Mat. Dan Mat. Terap., 2016.

[6] H. Hendriana, "Membangun Kepercayaan Diri Siswa Melalui Pembelajaran Matematika Humanis," J. Pengajaran Mat. Dan Ilmu Pengetah. Alam, 2014.

[7] T. Siswono And W. Novitasari, "Meningkatkan Kemampuan Berpikir Kreatif Siswa Melalui Pemecahan Masalah Tipe "What's Another Way"," J. Transform., 2007.

[8] I. Wijaya, M. Suastra, And M. Muderawan, "Pengaruh Model Pembelajaran Generatif terhadap Keterampilan Berpikir Kreatif dan Keterampilan Proses Sains," J. Pendidik. dan Pembelajaran Ipa Indones., Vol. 4, No. 1, 2014.

[9] H. A. Siti Mawaddah, "Kemampuan Pemecahan Masalah Matematis Siswa pada Pembelajaran Matematika dengan Menggunakan Model Pembelajaran Generatif (Generative Learning) di SMP," Edu-Mat J. Pendidik. Mat. Vol. 3, Nomor 2, Oktober 2015, Hlm 166 - 175, Vol. 3, Pp. 166-175, 2015.

[10] P. Akbar, A. Hamid, M. Bernard, and A. I. Sugandi, "Analisis Kemampuan Pemecahan Masalah dan Disposisi Matematik Siswa Kelas XI SMA Putra Juang dalam Materi Peluang," J. Cendekia J. Pendidik. Mat., Vol. 2, No. 1, Pp. 144-153, 2017.

[11] T. Y. E. Siswono, “Proses Berpikir Kreatif,” J. Ilmu Pendidik., 2008. 
[12] N. T. Rahmawati, "Kemampuan Berpikir Kreatif Matematik Siswa pada Pembelajaran SSCS dengan Tinjauan Metakognisi," Prism. Pros. Semin. Nas. Mat., 2016.

[13] N. H. Arifani, Sunardi, and S. Setiawani, "Tingkat Kemampuan Berpikir Kreatif Matematika Siswa Smp Kelas VIII di SMP Negeri 6 Jember, Smp Al Furqan 1, SMP Negeri 1 Rambipuji, dan SMP PGRI 1 Rambipuji," J. Kadikma, Vol. 6, No. 2, Pp. 159-172, 2015.

[14] Sucipta, E. Ahman, And N. Budiwati, "Metode Guided Discovery Learning terhadap Tingkat Berpikir Kritis Siswa Dilihat dari Motivasi Belajar," Indones. J. Econ. Educ., Vol. 1, No. 1, Pp. 1-8, 2018.

[15] T. Y. E. Siswono, "Mendorong Berpikir Kreatif Melalui Pengajuan Maslah (Problem Posing)," J. Math. Educ., 2004.

[16] W. Y. Isvina, T. Sugiarti, And D. Kurniati, "Proses Berpikir Kreatif dalam Memecahkan Masalah Sub Pokok Bahasan Trapesium Berdasarkan Tahapan Wallas ditinjau dari Adversity Quotient ( AQ ) Siswa Kelas VII-C SMP Negeri 1 Jember," Artik. Ilm. Mhs., 2015.

[17] S. Ratnapuri, N. Handayani, And W. Hidayat, "Analisis Kemampuan Berpikir Kreatif Matematis Siswa Kelas VIII SMP pada Sistem Persamaan Linear Dua Variabel (SPLDV)," Vol. 2, Pp. 1762-1771, 2018.

[18] D. Sulistiawati, "Pengaruh Model Pembelajaran Generatif," Vol. 2348, No. 02, Pp. 219-226, 2017.

[19] A. Murjani, "Meningkatkan Kemampuan Berpikir Kreatif dan Hasil Belajar Siswa Melalui Model Pembelajaran Generatif pada Materi Larutan Penyangga," Vol. 7, No. 2, Pp. 103-108, 2016.

[20] P. Masalah And M. Mahasiswa, "Model Pembelajaran Generatif (MPG) Berbantuan Blended Learning pada Trigonometri untuk Meningkatkan Kemampuan Pemecahan Masalah Matematis Mahasiswa PGRI," Vol. 2, No. November, Pp. 82-97, 2017.

[21] A. Wulandari, N. D. Muldayanti, and A. E. Setiadi, "Implementasi Model Pembelajaran Generatif terhadap Aktivitas dan Hasil Belajar Siswa ada Sub Materi Moluska di Kelas X SMA Negeri 01 Sungai Raya,” J. Bioeducation, 2016.

[22] N. Marliani, "Peningkatan Kemampuan Berpikir Kreatif Matematis Siswa Melalui Model Pembelajaran Missouri Mathematics Project (MMP)," Form. J. Ilm. Pendidik. Mipa, Vol. 5, No. 1, Pp. 14-25, 2015.

[23] J. W. Cresswell, Research Design. Pendekatan Kualitatif, Kuantitatif dan Campuran (Terjemahan). Yogyakarta: Pustaka Belajar, 2017.

[24] M. P. Dr. Wahidmurni, "Kuantitatif," Pemaparan Metod. Penelit. Kuantitatif, 2017.

[25] Made Wena, Strategi Pembelajaran Inovatif Kontemporer: Suatu Tinjauan Konseptual Operasional / Made Wena, No. March. 2013.

[26] A. R. Hakim, "Pengaruh Model Pembelajaran Generatif Terhadap," Form. J. Ilm. Pendidik. MIPA, Vol. 4, No. 3, Pp. 196-207, 2014.

[27] Y. N. Ekaputri, "Pengaruh Model Pembelajaran Generatif Terhadap Kemampuan Komunikasi Matematis Siswa Kelas VII MTsN Tarusan Kabupaten Pesisir Selatan," J. Kepemimp. Sekol. Dan Pengur. Sekol., Vol. 2, No. 2, Pp. 113-118, 2017.

[28] T. Y. E. Siswono, "Upaya Meningkatkan Kemampuan Berpikir Kreatif Siswa Melalui Pengajuan Masalah," Pendidik. Mat., 2005.

[29] J. Program and S. Pendidikan, "Kemampuan Berpikir Kritis Matematis Menggunakan Model Generative Learning dan Connecting, Organizing, Reflecting, Extending (CORE)," Vol. 9, No. 1, Pp. 108-117, 2020. 
[30] J. I. Pendidikan et al., "Pembelajaran Matematika Model Generative Learning dengan Performance Assessment untuk Meningkatkan Kemampuan Berpikir Kritis Matematis pada Siswa Kelas VIII," Vol. 3, No. 3, Pp. 63-74, 2017. 